\title{
KÄRÄJÄTUOMAREIDEN JA SYYTTÄJIEN KÄSITYKSET KUUNTELEMISESTA
}

\author{
Sanna Ala-Kortesmaa \& Tuula-Riitta Välikoski
}

\section{TIIVISTELMÄ}

Tutkimus selvittää suomalaisten käräjätuomareiden ja syyttäjien kuuntelemisen käsitteelle antamia merkityssisältöjä. Kuuntelemisen käsite on monitulkintainen, mutta yleisesti sen voidaan katsoa merkitsevän kognitiivista informaation organisointia ja sanoman kriittistä arviointia. Samalla sen voidaan nähdä olevan väline suhteiden rakentamisessa ja ylläpitämisessä sekä oppimisessa ja informaation yhdistelemisessä. (Imhof 2003.) Kuuntelemisen käsitteelle annetut merkityssisällöt myös ennustavat kuuntelemiskäyttäytymistä (Fitch-Hauser 1990; Imhof \& Janusik 2006, 81).

Oikeudellinen viestintäympäristö on kuuntelemisen kannalta haasteellinen tutkimuskohde sen toiminnan muodollisuuden, hierarkkisten rakenteiden ja osapuolten asymmetristen viestintäsuhteiden vuoksi (Välikoski 2004b). Käräjätuomareiden ja syyttäjien kuuntelemisen käsitteelle antamia merkityssisältöjä päästiin tutkimuksessa tarkastelemaan Imhofin ja Janusikin (2006) kuuntelemisen mittarin (Listening Concepts Inventory) avulla. Vastaajat arvioivat kuunnella-verbin läheisyyttä Likert-asteikolla 48 verbiin. Tutkimukseen osallistui 96 syyttäjääja 24 käräjätuomaria.

Tutkimuksessa vastaajat antoivat kuuntelemisen käsitteelle merkityssisältöjä, jotka liittyivät informaation organisointiin kriittisesti sekä informaation omaksumiseen ja integrointiin mutta eivät suhteiden rakentamiseen ja ylläpitämiseen. Tulos vahvistui koko aineistossa taustamuuttujista riippumattaja poikkesi selväst $i$ aiemmista tuloksista.

Asiasanat: kuunteleminen, oikeussaliviestintä, kuuntelemisen käsitykset 


\section{JOHDANTO}

Kuunteleminen ei ole vain puhumisen passiivinen vastakohta. Se on keskeinen osa vuorovaikutusta ja aktiivista viestintäkäyttäytymistä - ilman kuuntelemista vuorovaikutus ei olisi prosessi. Kuunteleminen on myös ensimmäinen viestinnän muoto, jonka lapsi oppii, ja sitä käytetään viestintätaidoista useimmin läpi elämän (Wolvin \& Coakley 2000). Se on myös tärkeä sosiaalinen taito (Haavisto 2002; Mikkola 2006; Tiuraniemi 2004; Välikoski 2000; 2004a). Useimmissa yksityis- ja työelämän viestintätilanteissa tavoitteena on, että kuunteleminen olisi tehokasta. Tämä kuitenkin edellyttää, että viestijä osaa kuunnella sekä kognitiivisesti että behavioristisesti tarkoituksenmukaisella tavalla. Tehokas kuuntelemisprosessi vaatii keskittymiskykyä, työmuistia ja tarkkaavaisuutta. Työelämässä keskustelukumppanin ymmärtämiseen tähtäävän kuuntelemisen on perinteisesti todettu olevan avainasemassa toimivaa vuorovaikutusta ylläpidettäessä (Brownell 2002; Rogers \& Rothelisberger 1952), mikä kuitenkin on usein haasteellista. Gabarro (1991) esimerkiksi kuvaa "johdon paradoksiksi" tilannetta, jossa johtajan olisi pystyttävä tuomitsematta kuuntelemaan alaisiaan ja ymmärtämään näiden näkökantoja ja samalla tekemään asemansa edellyttämiä päätöksiä.

Kuuntelemiskäsityksellä tarkoitetaan sitä, miten viestijä ymmärtää kuuntelemisen ja millaisia merkityssisältöjä hän antaa sille. Kuuntelemiseen liittyvien käsitysten on myös määritelty olevan subjektiivisia, kognitiivisia rakenteita, jotka määräävät, millä tavalla viestijä kuuntelee (Fitch-Hauser 1990).

Kuuntelemiskäsitykset määrittävät sekä yleistä kuuntelemiskäyttäytymistä että tiettyyn tilanteeseen liittyvää kuuntelemisprosessia. Neljän yleisimmän kuuntelemiskäsityksen on havaittu suuntaavan kuuntelemista kognitiiviseen informaation organisointiin, sanoman kriittiseen arviointiin, suhteiden rakentamiseen sekä oppimiseen ja informaation yhdistelyyn. (Imhof \& Janusik 2006, 89-91.) Kuuntelemiseen liittyvät käsitykset ja niiden vaikutukset viestintäkäyttäytymiseen ovat läsnä kaikessa vuorovaikutuksessa, mutta erityisesti oikeussaliympäristössä niiden merkitys on suuri, sillä toiminnan muodollisuudessa, tilanteessa ilmenevissä hierarkkisissa rakenteissa ja osapuolten asymmetrisissa viestintäsuhteissa on suuria eroja. (Välikoski 2004b.)

Kuunteleminen on monelle arkipäiväinen asia, mutta se on myös aktiivisesti kehitettävissä oleva toiminto, joka sisältyy viestintäosaamisen perustekijöihin ollen myös tärkeä osa erilaista ammattiosaamista (Kostiainen 2003). Kuunteleminen ilmiönä ja esimerkiksi työyhteisötaitona on kirjattu erilaisiin säädöksiin ja määräyksiin (mm. Työturvallisuuslaki 738/2002, yliopistojen uudet palkkausjärjestelmät). 


\section{OIKEUDENKÄYNTIUUDISTUS JA SUULLISEN VUOROVAIKUTUKSEN LISÄÄNTYMINEN}

Vaikka kuunteleminen ilmiönä on ollut oikeudellisessa ja hallinnollisessa viestintäympäristössä läsnä jo pitkään, esimerkiksi henkilön oikeutena tulla kuulluksi ennen häntä itseään koskevaa päätöksentekoa (mm. Hallintolaki 434/2004; Suomen Hallitusmuoto 94/1919), on tästä ympäristöstä tehty kuuntelemisen ja vuorovaikutuksen tutkimus vielä vähäistä. Vasta 1990 -luvun suullisuutta ja välitöntä vuorovaikutusta korostava oikeudenkäyntiuudistus muutti oikeudenkäyntiä vuorovaikutustilanteena siten, että oli mielekästä alkaa tarkastella oikeussaliviestintää vuorovaikutuksen ja kuuntelemisen näkökulmasta (Ervasti 1997; Haavisto 2002; Välikoski 2004b). Uudistuksen mukaan oikeudenkäynnin tulee olla keskitettyä, välitöntä ja suullista, mikä tarkoittaa sitä, että kaikki oikeudenkäyntiaineisto esitetään suullisesti, yhtäjaksoisesti ja samassa tuomioistuinkokoonpanossa. Oikeuden päätökset voivat lisäksi perustua vain materiaaliin, joka on suullisesti esitetty pääkäsittelyssä. (HE 32/2001vp; LaVM 12/2002vp; RoL 97/689.)

Uudistuksen myötä vuodesta 1998 syyttäjän tehtävät muuttuivat perusteellisesti. Nykyään syyttäjä tekee suullisesti asiaesittelyn ennen vastaajan tai tämän avustajan antamaa vastausta syytteeseen, aloittaa todistajan kuulustelemisen ja esittää loppulausuntonsa ensimmäisenä. (Koponen 2004, 8; RoL 97/689.) Syyttäjä pyrkii alkupuheenvuorossaan luomaan yhteisen ymmärryksen siitä, mitä on tapahtunut. Tällöin viestinnällisessä keskiössä on sanoman esittely. Syytteen selostusosassa syyttäjä kuvailee omin sanoin tapahtuman kulkua. Todistelussa asian käsittely jatkuu kysymys-vastaustyyppisenä keskusteluna. Todistajien kuulustelussa syyttäjän ohjaaman vuorovaikutuksen merkitys korostuu, sillä todistajat ovat kokeneet luontevien ja avoimeksi koettujen viestintäsuhteiden helpottavan todistamista (Välikoski 2000). Loppukeskustelussa syyttäjän puheenvuoro puolestaan koostuu sekä valmistellusta että oikeussalissa kuullusta ja siitä prosessoidusta informaatiosta (Välikoski 2004a, 15-16). Koska erityisesti loppupuheenvuoron tarkoituksena on vakuuttaa tuomioistuin tapahtuneesta, syyttäjän kuunteleminen ja siihen liittyvät käsitykset vaikuttavat todennäköisesti siihen, millaiseksi tämä puheenvuoro muotoutuu.

Syyttäjän käsityksen istuntokäsittelystä viestintätilanteena on todettu olevan puhujakeskeinen. Vuorovaikutus on syyttäjän näkökulmasta perättäistä, ja sen onnistuminen riippuu puhujasta. Myös loppupuheenvuoro on ymmärrettävästi koettu vaikeaksi monologiluonteensa perusteella. Samoin syyttäjien on todettu kiinnittävän paljon huomiota nonverbaalisiin tekijöihin istuntokäsittelyn aikana ja jättävän lautamiehet viestinnällisesti lähes täysin huomiotta oikeussalissa. (Välikoski 2004a.)

Lakiuudistusten myötä myös käräjätuomarin tehtävät ovat muuttuneet. Vuoden 2006 alusta voimaantulleet Laki riita-asioiden sovittelusta yleisissä tuomioistuimissa 26.8.2005/663 ja Laki rikosasioiden ja eräiden riita-asioiden sovittelusta 9.12.2005/1015 määräsivät, että käräjätuomari ei vain kannusta 
osapuolia sovittelemaan vaan myös tekee sovittelijana kompromissiehdotuksen niissä tapauksissa, joissa se on mahdollista. Uusien lakien myötä jo vuoden 1993 uudistuksessa esitetty ajatus (Lakia rikosasioiden käsittelystä valmistelevan työryhmän mietintö 1/1993) istuntotoiminnan selkeydestä ja havainnollisuudesta korostui ja kuuntelemisen merkitys ymmärtämisen välineenä entisestään vahvistui.

Oikeudellinen sovittelu on tilanteena epämuodollisempi ja välittömämpi kuin istuntokäsittely, joten lienee ilmeistä, että siinä korostuu toimiva vuorovaikutus. Riitatilanteen osapuolet ovat aktiivisia hakiessaan sovintoa, ja sovittelijatuomarin on kuultava, mitä he sanovat. Oleellista on kuitenkin myös se, mitä osapuolet kuulevat ja havaitsevat. (Ks. Haavisto 2002 ritatilanteen sovittelusta haastehakemuksen jättämisen jälkeen.) Koska tilanteen kokeminen vaikuttaa ihmisten viestintäkäyttäytymiseen, on sovittelua johtavan käräjätuomarin kuuntelemiskäsitysten kartoittaminen erityisen perusteltua, sillä tilanteessa neutraalina osapuolena hän voi omaa viestintä- ja kuuntelemisosaamistaan hyödyntäen osoittaa, että molempien osapuolten mielipiteitä kuunnellaan (Ala-Kortesmaa $2008,108)$.

\section{KUUNTELEMINEN}

Kansainvälisen kuuntelemiseen keskittyvän tutkimuksen laaja kirjo heijastaa tutkittavan ilmiön, kuuntelemisen, monitasoisuutta. Kuuntelemisen käsite on muun muassa esitelty tutkimuksissa samanlaisena kuin erilaisissa kuuntelemista mittaavissa testeissä (Fitch-Hauser \& Hughes 1992; Villaume \& Weaver 1996), ja tehokkaalle ja tilanteeseen sopivalle kuuntelemiselle on osoitettu olevan erilaisia esteitä (Golen 1990). Kuuntelemiskäyttäytymisen on lisäksi todettu olevan yhteydessä paitsi yksilön (Bond ym. 2008) myös organisaation hyvinvointiin (Gilchrist \& Van Hoeven 1994; Koivunen 2007) ja organisaatiokulttuuriin (Brownell 2002; Cooper 1998; Imhof 2003). Kuuntelemiseen on fyysisen kuulemistoiminnon lisäksi liitetty myös monitasoiset ja kognitiivisesti vaativat toiminnot kuten sanoman ymmärtäminen, muistaminen, tulkitseminen ja arviointi sekä siihen vastaaminen (Brownell 1990; 2002, 73).

Kuuntelemiseen sisältyvät viestintätapahtumaan liittyvät ennakko-oletukset, kuunteleminen fyysisenä tapahtumana, viestin vastaanottaminen, viestin semanttinen prosessointi ja viestiin vastaaminen. Samalla siihen liittyy kuitenkin myös nonverbaalisen viestinnän tarkasteleminen ja tulkitseminen, sillä paljon kuunneltavaan viestiin liittyvää, sitä tukevaa tai horjuttavaa informaatiota sisältyy muun muassa ilmeisiin, eleisiin ja tilan käyttöön. Se, mitä kuunnellaan, on tilannekohtaista. Kuuntelemalla voidaan esimerkiksi hankkia tietoa, jos kuuntelemisella pyritään pelkästään välitetyn viestin sisältämän informaation omaksumiseen, tai vahvistaa ihmissuhteita, jos tarkoituksena taas on esimerkiksi viestintäkumppanin tilanteessa myötäeläminen. Kuunteleminen ilmentää vuorovaikutussuhdetta ihmisten välillä. Kuuntelijan itsensä ei kuitenkaan vält- 
tämättä tarvitse olla osa intentionaalista vuorovaikutussuhdetta (vrt. kanssamatkustajien keskustelun kuunteleminen ja siihen osallistuminen tai sen pelkkä seuraaminen junassa). (Ks. Bostrom 1997.)

Suomalaista kuuntelemisen tutkimusta on tehty runsaasti lääketieteen, logopedian ja vokologian aloilla. Tällöin on tutkittu kuulemista, kuulo-ongelmia tai miten analysoida ja erotella kuuntelun perusteella erilaisia ääniä ja äänteitä (Korpijaakko-Huuhka, Pekkala \& Heimo 2005; Laukkanen, Björkner \& Sundberg 2005). Tutkimusta on tehty myös kognitiivisen psykologian alalla ja selvitetty, miten kuunteleminen on yhteydessä oppimiseen ja esimerkiksi lukemaan oppimiseen (Mäkinen 2005) tai vieraiden kielten oppimiseen (Halsband ym. 2002; Huhta ym. 1997). Joitakin sosiaalipsykologian ja sosiologian tutkimuksia on tehty, joissa kuuntelemiseen on erityisesti viitattu ryhmädynamiikan tai asiakassuhteiden hoitamisen välineenä (Peräkylä 2004; Suoninen 2005).

Kuuntelemisen tutkimus osana puheviestintäosaamista on vielä melko niukkaa, ja tutkimuksissa on usein käytetty instrumentteja, jotka mittaavat ulkopuolisten havaintojen avulla henkilön kuuntelemista (Nyfors 1995; Valkonen 2001). Tällainen tutkimus keskittyy analysoimaan sitä, miten kuunteleminen näkyy, ja tutkimuskohteena voi olla esimerkiksi nonverbaalisen käyttäytymisen tarkastelu tai kuullusta informaatiosta annettu verbaalinen palaute. Tällöin tutkitaan kuuntelemisen tulosta eli havaittavaa käyttäytymistä kuuntelemisprosessin sijaan (Välikoski ym. 2005).

Vasta viimeaikaisessa tutkimuksessa huomio on kiinnitetty kuuntelemisprosessin ja kuuntelemiseen liittyvien käsitysten tutkimiseen (Imhof \& Janusik 2006, 82). Myös suomalainen opiskelija-aineisto oli vertailuaineistona vuosina 2004-2005 tutkimuksessa, jossa testattiin yksilön kuuntelemisen kapasiteettia keskustelutilanteessa Conversational Listening Span (CLS) -mittarin eli keskustelukuuntelun aikajännemittarin avulla. Mittaria oli aiemmin testattu yhdysvaltalaisella opiskelija-aineistolla, ja todettu se validiksi. (Välikoski ym. 2005.)

Kuuntelemiseen liittyvillä käsityksillä on yhteys havaittuun käyttäytymiseen (Imhof \& Janusik 2006, 81), ja siksi uusien kuuntelemistutkimuksien haasteena onkin viestin lähettämisen ja vastaanottamisen ohella tutkia myös kuuntelemisen yhteyttä viestijöiden väliseen vuorovaikutussuhteeseen. Oikeussaliviestinnässä tämän yhteyden tarkastelu on erityisen tärkeää, sillä esimerkiksi käräjätuomarin ohjailemassa sovittelussa osapuolten välisellä toimivalla vuorovaikutussuhteella lienee yhteys sovittelun tulokseen. Kirjallisia muistioita sovittelun etenemisestä ei tehdä. Näin ollen tuomarin on sovittelua johtaessaan saavutettava osapuolten luottamus siihen, että hän kuuntelemalla tasapuolisesti kaikkia osaa ehdottaa molempien osapuolten näkökulmasta toimivaa sovitteluratkaisua tai ohjata heitä sitä kohti (Ala-Kortesmaa 2008, 107). 


\section{TUTKIMUKSEN TOTEUTTAMINEN}

\section{Tavoite}

Tutkimuksen tavoitteena oli selvittää, millaisia merkityssisältöjä istuntokäsittelyissä työskentelevät käräjätuomarit ja syyttäjät antavat kuuntelemisen käsitteelle. Koska kuuntelemiskäsityksiin liittyvää kirjallisuutta ei ole paljon, hypoteesilähtöisyyden sijasta päätettiin pyrkiä tutkimuksen tavoitteeseen tutkimuskysymysten avulla.

Päätutkimuskysymykseksi asetettiin seuraava:

1. Millaisia kuuntelemiseen liittyviä käsityksiä käräjätuomareilla ja syyttäjillä on?

Taustamuuttujien antamaa lisätietoa haettiin seuraavilla tutkimuskysymyksillä:

2. Miten eri sukupuolten kuuntelemiskäsitykset eroavat toisistaan?

3. Miten eri ikäryhmien kuuntelemiskäsitykset eroavat toisistaan?

4. Miten eri virkavuosiryhmiin kuuluvien kuuntelemiskäsitykset eroavat toisistaan?

\section{Mittarin esittely ja arviointi}

Tutkimus keskittyi kuuntelemiseen liittyvien käsitysten tarkasteluun semanttisten mielleyhtymien avulla, ja aineisto kerättiin Imhof-Janusik Listening Concepts Inventory (jatkossa LCI) -mittarilla (Imhof \& Janusik 2006; ks. liite 1). Mittarilla on mahdollista kerätä numeerista tietoa niistä merkityssisällöistä, joita kuuntelemisen käsitteelle annetaan.

Mittaria laatiessaan sen kehittäjät Imhof ja Janusik (2006) pyrkivät rakentamaan kuuntelemisen semanttisen kentän vastaamaan kuuntelemiseen liittyviä käsityksiä. Pohjatutkimusta, jonka avulla mittaria alettiin rakentaa, oli niukasti, ja se perustui pääasiassa perinteisten kuuntelemistestien tuottamaan aineistoon. Kaikkien näiden testien validiteettia ei ole aukottomasti todettu. Koska kuuntelemisen tutkimusta on systemaattisesti tehty vasta 1990-luvulta lähtien, LCI-mittarin kehittäjät hyödynsivät myös alan muuta kirjallisuutta valitessaan mittariinsa 80 kuuntelemisen semanttista kenttää hahmottavaa verbiä, jotka oli puheviestinnän alalla liitetty kuuntelemiseen (Bostrom 1997; Brownell 2002; Nichols 1948; Wolvin \& Coakley 2000).

Tutkijat halusivat yhdistää mittarissa käytettyjen verbien joukkoon myös maallikoiden kuuntelemiseen liittäviä verbejä, jotka valittiiin Roget'n Thesauruksesta ja Merriam Webster Online Thesauruksesta. Testattaessa mittarin validiutta sekä englannin- että saksankielisenä versiona verbilista lyheni käsittämään 65 verbiä. Tuoreimmassa mittariversiossa on 48 verbiä - luku syntyi, kun 65 verbin listasta poistettiin verbit, jotka eivät latautuneet yhdellekään aiem- 
masta neljästä kuuntelemiseen liittyviä käsityksiä kuvaavasta faktorista tai jotka aina latautuivat useammalle faktorille (vrt. Bodie, Välikoski \& Worthington 2008; Imhof \& Janusik 2006). Tässä tutkimuksessa käytetään 48 verbin mittaria. Sen luomiseksi kaksi suomen natiivipuhujaa käänsi alkuperäisen englanninkielisen verbilistan suomeksi toisistaan tietämättä. Jos verbien käännökset eivät vastanneet suomenkielisessä versiossa toisiaan, eroista keskusteltiin kolmannen suomenkielisen puhujan kanssa ja merkityksiin liittyviin ongelmiin etsittiin kaikkia osapuolia tyydyttävä ratkaisu. Tämän jälkeen englannin natiivipuhuja käänsi suomenkielisen listan takaisin englanniksi, jotta nähtiin, vastaavatko alkuperäinen englanninkielinen verbilista ja suomesta takaisin englanniksi käännetty verbilista toisiaan. Näin varmistettiin, että listan verbien merkityksissä ei tapahtunut muutoksia kääntämisvaiheessa, ja pyrittiin saamaan listasta mahdollisimman kattava kuuntelemiselle annettavia sisältömerkityksiä ajatellen. Täydellistä, kaikki sisältömerkitykset kattavaa listaa on kuitenkin mahdotonta luoda, sillä käsitteisiin liittyvien semanttisten kenttien rakentuminen on yksilökohtaista.

Mittari siis sisältää 48 aktiivista ja passiivista toimintaa kuvaavaa verbiä, joiden herättämää välitöntä mielleyhtymää ja sen semanttista läheisyyttä kuunnella-verbiin vastaajat arvioivat Likert-tyyppisen asteikon (identtinen $=5$ [kuuntelemisen kanssa], lähes identtinen $=4$, melko samanlainen $=3$, jotenkin tekemisissä $=2$ ja ei lainkaan lähellä $=1$ [kuuntelemista]) avulla (ks. liite 1). Asteikosta pyrittiin luomaan selkeä. Identtinen-sanalla viitattiin täydelliseen samankaltaisuuteen, lähes identtinen -ilmauksella taas miltei täydelliseen vastaavuuteen. Eroa tämän ja melko samanlainen -ilmauksen välille pyrittiin luomaan valitsemalla täysin eri sana (identtinen vs. samanlainen) kuvaamaan kaukaisempaa yhteyttä kuunnella-verbiin. Eroa kasvatettiin tämän jälkeen valitsemalla jotenkin tekemisissä -ilmaus, joka ei enää kuvaa samankaltaisuutta, ja lopuksi ei lainkaan lähellä -ilmauksella päädyttiin mittarin toiseen ääripäähän, jossa mielleyhtymä ei ole enää lähellä kuunnella-verbiä. Mittarilla ei pyritä saamaan esiin kausaalisuuksia vaan luotaamaan kuunnella-verbin sijoittumista vastaajan semanttiseen merkityskenttään.

Tämän tutkimuksen tuloksia tarkastellessa on hyvä pitää mielessä, että Imhofin ja Janusikin (2006) LCI-mittari on kehittelyvaiheessa oleva tuore instrumentti. Mittarilla saatavien tulosten validius ja johdonmukaisuus kuitenkin osoittavat, että mittari sopii kuuntelemiseen liittyvien käsitysten tarkasteluun. Kuten mittarin aiemmissa versioissa on havaittu, verbien semanttiset merkitykset vaihtelevat kieli- ja kulttuurialueittain, sillä alkuperäisestä 80 verbin listasta jäi 25 verbiä pois kielialuetta vaihdettaessa. Suomenkielisessä ympäristössä on käytetty sekä 65 että 48 verbiä sisältävää mittaria.

\section{Aineiston keruu}

Tutkimusaineisto kerättiin syyttäjien ja käräjätuomareiden ammatillisten täydennyskoulutuskurssien yhteydessä syksyllä 2007. Täydennyskoulutuskurssit 
olivat osallistujille vapaaehtoisia, ja niiden kurssisisällöt liittyivät suoraan osallistujien erilaisiin työtehtäviin. Tämän tutkimuksen tekijät eivät olleet kursseilla mukana. Kurssisihteerit jakoivat tutkimukseen liittyvän kyselyn vastaajille ja kertoivat suullisesti, että tutkimuksen tarkoituksena on selvittää, miten kyseinen ryhmä ymmärtää kuuntelemisen. Työtehtävää ei tarvinnut pitää mielessä arviota tehdessä. Lomakkeessa oli osallistujille ääneen luettua kyselysaatetta niukempi ohjeistus lomakkeen täyttämisestä (ks. liite 1). Vastaajat täyttivät lomakkeen kurssin lopussa ja jättivät vastauksensa anonyymisti kurssisaliin. Vastaajien poistuttua kurssisihteeri kävi keräämässä vastaukset ja lähetti ne tutkimuksen tekijöille.

Kyselyyn vastasi yhteensä 120 henkilöä: 96 syyttäjää ja 24 käräjätuomaria. Tutkimuksen taustamuuttujina olivat sukupuoli, ikä ja syyttäjillä virkavuodet. Kuten taulukko 1 osoittaa, vastaajista 7,5\% ei ilmoittanut sukupuoltaan, ja vastauksen antaneiden sukupuolijakauma oli hyvin tasainen.

TAULUKKO 1. Vastaajien sukupuolijakauma $(N=120)$

\begin{tabular}{|l|c|c|}
\hline Sukupuoli & Lukumäärä & Prosentti \\
\hline Ei vastausta & 9 & 7,5 \\
\hline Mies & 53 & 44,2 \\
\hline Nainen & 58 & 48,3 \\
\hline
\end{tabular}

Taulukosta 2 havaitaan, että myös vastaajien ikäjakauma oli tasainen.

TAULUKKO 2. Vastaajien ikäjakauma ( $N=120)$

\begin{tabular}{|l|c|c|}
\hline Ikä & Lukumäärä & Prosentti \\
\hline Ei vastausta & 33 & 27,5 \\
\hline $25-30$ vuotta & 3 & 2,5 \\
\hline $31-35$ vuotta & 13 & 10,8 \\
\hline $36-40$ vuotta & 16 & 13,3 \\
\hline $41-45$ vuotta & 17 & 14,2 \\
\hline $46-50$ vuotta & 28 & 23,3 \\
\hline
\end{tabular}

Tietoa virkavuosien määrästä kerättiin vain syyttäjiltä. Käräjätuomareiden kohdalla tämän informaation keräämistä ei katsottu tarpeelliseksi, sillä laki, joka takaa osapuolille mahdollisuuden sovitella riita-asioita ilman haastehakemuksen jättämistä, on ollut voimassa vasta vuoden 2006 alusta lähtien. Haastehakemuksen jättämisen jälkeen sovittelu on ollut mahdollista oikeudenkäyntiuudistuksesta lähtien. Lakimuutoksen myötä käräjätuomareille tuli myös velvollisuus ohjata kiistan osapuolia yrittämään sovintoratkaisua, mikä tullee johtamaan sovittelujen lisääntyneeseen määrään. Sen sijaan syyttäjien viestinnälliseen roo- 
liin oikeudenkäyntiuudistus on ehtinyt vaikuttaa merkittävästi jo kymmenen vuoden ajan. Taulukosta 3 näkee, että syyttäjistä noin kolmanneksella oli työkokemusta tehtävästään alle 11 vuotta, kolmanneksella oli virkavuosia takanaan 11 tai enemmän ja kolmannes vastaajista jätti vastaamatta kysymykseen.

TAULUKKO 3. Syyttäjien virkavuodet $(N=96)$

\begin{tabular}{|l|c|c|}
\hline Virkavuodet & Lukumäärä & Prosentti \\
\hline Ei vastausta & 34 & 35,4 \\
\hline Alle 5 vuotta & 11 & 11,5 \\
\hline $6-10$ vuotta & 19 & 19,8 \\
\hline $11-15$ vuotta & 12 & 12,5 \\
\hline $16-20$ vuotta & 8 & 8,3 \\
\hline
\end{tabular}

\section{Aineiston analyysi}

Aineisto analysoitiin SPSS for Windows 16.0 -ohjelmalla käyttäen faktorianalyysia, jonka avulla on mahdollista löytää ja tulkita piilevät faktorit eli tekijät, jotka saavat aikaan havaittavien muuttujien arvot (ks. Golen 1990). Faktorianalyyttisen lähestymistavan avulla pyrittiin toisin sanoen löytämään mahdolliset kuuntelemisen käsityksiä edustavat semanttiset kasaumat verbien latautumisessa eri faktoreille. Ennen aineiston analysointia kuitenkin tarkistettiin, onko käytettävä korrelaatiomatriisi sovelias faktorianalyysiin. Käytetyt menetelmät olivat Kaiserin testi (Kaiser-Meyer-Olkin Measure of Sampling Adequacy eli $\mathrm{KMO}$ ) ja Bartlettin sfäärisyystesti, jotka ilmaisevat muuttujien välistä korreloituneisuutta ja osoittavat korrelaatiomatriisin kelvollisuuden faktorianalyysiin. Kaiserin testin arvon tulisi olla suurempi kuin 0,6 ja Bartlettin testin tilastollisesti merkitsevä. (Metsämuuronen 2003, 543.) Nämä vaatimukset täyttyivät KMO-testin ollessa ,872 ja Bartlettin testin merkitsevyyden ollessa pienempi kuin ,001.

Eksploratiivisen faktorianalyysin avulla etsittiin LCI-mittarin verbijoukosta piilomuuttujia eli faktoreita, jotka pystyivät selittämään havaittujen muuttujien vaihtelua ilman, että löydettävien faktoreiden märästä tai niiden tulkinnasta oli ennakko-odotuksia. Varsinainen pääkomponenttianalyysi Varimax-rotaatiolla (Kaiserin normalisaatiolla ja Eigenvaluen arvolla 1) antoi 11 faktoria, jotka sopivat tarkasteltaviksi. Koska sellaisten faktorien tulkinta ei ole suotavaa, joille latautuu vähemmän kuin neljä arvon 0,60 ylittävää muuttujaa (Guadagnoli \& Velicer 1988), tulosten lopullinen tulkinta oli suurimmassa osassa aineistoryhmistä rajattava kolmeen faktoriin. Fürntrattin kriteeriä $\left(\mathrm{a}^{2} / \mathrm{h}^{2}>0,50\right)$ käytettiin alustavasti faktorien tulkinnan perustana. Verbit, jotka eivät täyttäneet tätä kriteeriä, jätettiin tarkastelun ulkopuolelle. Verbit, joiden lataumat ylittivät Fürntrattin kriteerin mutta jäivät alle $0,60: \mathrm{n}$, pidettiin mukana, koska niiden katsottiin antavan lisäinformaatiota faktoreille latautuvista semanttisista kasaumista. (Ks. 
liite 2.) Syntyneiden kolmen faktorin reliabiliteetit testattiin käyttämällä Cronbachin Alphaa (ks. taulukko 4 luvussa "Tulokset"). Tutkimuksessa löydetyt faktorit nimettiin niiden verbien mukaan, joiden latautuminen indeksimuuttujina oli tilastollisesti merkitsevää. Kahdelle faktorille latautui yhteensä kolme verbiä tai verbi-ilmausta, joiden merkitykset erosivat hieman muista kyseisille faktoreille latautuneista verbeistä. Faktoreiden nimeämisessä kuitenkin pyrittiin huomioimaan tilastollisesti merkitsevien lataumien merkityssisällöt kokonaisuutena, jolloin nämä yksittäiset verbit tai verbi-ilmaukset eivät vaikuttaneet koko faktorin nimeämiseen. Nimeäminen suoritettiin samansuuntaisesti kuin Imhofin ja Janusikin $(2006,86)$ tutkimuksessa, jossa neljä pääfaktoria oli nimetty niille latautuneiden indeksimuuttujien mukaan seuraavasti: informaation organisointi, sanoman kriittinen arviointi, suhteiden rakentaminen sekä oppiminen ja informaation yhdistely.

Seuraavaksi aineisto jaettiin kahteen ryhmään sukupuolen perusteella, viiteen ikäryhmään ja syyttäjät kahteen virkavuosien määrään pohjaavaan ryhmään. Keskiarvot ja keskihajonnat laskettiin. Tämän jälkeen faktorianalyysin antamia tuloksia tarkasteltiin taustamuuttujien mukaan, jotta saataisiin selville muuttujien ja vastaajien käsitteille antamien merkityssisältöjen välinen yhteys. Lopuksi tuloksia verrattiin aikaisempiin tutkimuksiin (Artkoski 2008; Bond ym. 2008; Imhof \& Janusik 2006).

\section{TULOKSET}

Tutkimuksessa selvitettiin LCI-mittarin avulla suomalaisten käräjäoikeustuomareiden ja syyttäjien käsityksiä kuuntelemisesta. Verbien saamia keskiarvoja ja keskihajontaa tarkasteltaessa selvisi, että vastaajat sijoittivat verbi-ilmauksen kuunnella tarkasti $(\mathrm{ka}=3,46 ; \mathrm{kh}=1,420)$ merkitykseltään kaikista lähimmäksi verbiä kuunnella. Seuraavaksi lähimmäksi merkitykseltään miellettiin verbit ja verbi-ilmaukset havainnoida $(\mathrm{ka}=3,42 ; \mathrm{kh}=1,017)$, kerätä informaatiota (ka $=3,23 ; \mathrm{kh}=, 991)$ ja purkaa sanoma, jäsentää $(\mathrm{ka}=2,92 ; \mathrm{kh}=1,078)$. Kaikista kaukaisimpina merkitykseltään suhteessa verbiin kuunnella vastaajat pitivät listan verbejä ja verbi-ilmauksia pantata tietoa $(\mathrm{ka}=1,44 ; \mathrm{kh}=, 838)$, antaa myöten/periksi $(\mathrm{ka}=1,58 ; \mathrm{kh}=, 866)$, tehdä ehdotus $(\mathrm{ka}=1,64 ; \mathrm{kh}=1,002) \mathrm{ja}$ testata $(\mathrm{ka}=1,65 ; \mathrm{kh}=1,001)$. (Ks. liite 2 .)

Tämän tutkimuksen tulokset latautuivat vain kolmelle faktorille, mikä johti faktorien nimien ja sisältöjen uudelleenmäärittelyyn (ks. liite 2). Kuten taulukosta 4 voidaan havaita, faktoreiden nimeksi annettiin Informaation kriittinen organisointi, Informaation integrointi ja Informaation omaksuminen.

Faktorit selittivät 51,96\% kokonaisvarianssista. Tuloksena tämä on hyvä, sillä kolme faktoria yhdestätoista kattoi yli puolet kokonaisvarianssista.

Verbit, jotka latautuivat faktorille Informaation kriittinen organisointi, kuvaavat pääosin tietoisen ja aktiivisen informaation prosessointia, joka tapahtuu työmuistissa: verrata, arvioida, perustella, olla kriittinen ja vetää johtopää- 
tös. Faktori kuitenkin sisälsi myös vuorovaikutusta kuvaavia verbejä, jotka ovat relevantteja molemminpuolisen suostuttelun ja kuuntelemisen kannalta, kuten tehdä ehdotus, sopia ja auttaa. Informaation kriittistä organisointia kuvaava faktori selitti 41,43\% kokonaisvarianssista.

\begin{tabular}{|c|c|c|c|c|}
\hline Faktori & Latautuneet verbit & \begin{tabular}{|l} 
Verbin \\
erottuminen
\end{tabular} & $\begin{array}{l}\text { Cronbachin } \\
\text { Alpha/faktori }\end{array}$ & $\begin{array}{l}\text { Verbien Ikm } \\
\text { faktoria kohden }\end{array}$ \\
\hline \multirow{17}{*}{$\begin{array}{l}\text { Informaation } \\
\text { kriittinen } \\
\text { organisointi }\end{array}$} & keskeyttää &, 732 & ,962 & 17 \\
\hline & verrata & 697 & & \\
\hline & arvioida & 691 & & \\
\hline & perustella &, 783 & & \\
\hline & olla krittinen & .738 & & \\
\hline & tehdä ehdotus & ,668 & & \\
\hline & vetää johtopäätös & 633 & & \\
\hline & vastata kysymyksiin & .733 & & \\
\hline & pantata tietoa &, 768 & & \\
\hline & antaa myöten/periksi & 671 & & \\
\hline & sopia &, 745 & & \\
\hline & auttaa &, 664 & & \\
\hline & testata &, 773 & & \\
\hline & tiedustella &, 642 & & \\
\hline & olla varuillaan &, 750 & & \\
\hline & toivottaa tervetulleeksi &, 713 & & \\
\hline & ymmärtää (aavistaa) &, 737 & & \\
\hline \multirow{7}{*}{$\begin{array}{l}\text { Informaation } \\
\text { integrointi }\end{array}$} & analysoida &, 798 & 901 & 7 \\
\hline & nauttia jostakin &, 825 & & \\
\hline & valikoida &, 774 & & \\
\hline & ymmärtää & .636 & & \\
\hline & arvostaa &, 716 & & \\
\hline & erotella &, 783 & & \\
\hline & tulkita & .688 & & \\
\hline \multirow{4}{*}{$\begin{array}{l}\text { Informaation } \\
\text { omaksuminen }\end{array}$} & kerätä informaatiota &, 702 &, 758 & 4 \\
\hline & havainnoida & .643 & & \\
\hline & varastoida informaatiota & .753 & & \\
\hline & tulla tietoiseksi & 692 & & \\
\hline
\end{tabular}

Taulukko 4. Verbien latautuminen eri faktoreille, Cronbachin Alphat $(N=120)$

Toinen faktori Informaation integrointi sisälsi verbejä, jotka viittaavat informaation hyödyntämiseen ja prosessointiin sekä uuden ja aiemmin omaksutun informaation integrointiin. Esimerkiksi verbit tulkita, valikoida ja ymmärtää latautuivat tälle faktorille, joka selitti 5,63\% kokonaisvarianssista. Kolmas faktori 
Informaation omaksuminen puolestaan koostui verbeistä ja verbi-ilmauksista, jotka liittyvät varsinaiseen uuden informaation hankintaan ja sen muistiin painamiseen, kuten havainnoida, tulla tietoiseksi ja varastoida informaatiota. Faktori selitti $4,90 \%$ kokonaisvarianssista.

Tutkimuksen taustamuuttujina olivat sukupuoli, ikä ja virkavuosien määrä. Tulosten perusteella tutkimuksessa eri faktoreille latautuneiden vastausten välillä ei ollut merkittäviä sukupuoleen perustuvia eroja siinä, millaisia laadullisesti erilaisia kuuntelemiseen liittyviä käsityksiä vastaajilla on. Verbit, jotka latautuivat merkitsevästi (arvo > ,600) molempien sukupuolten vastauksissa (ks. liite 3), latautuivat yhtä poikkeusta lukuun ottamatta (kohdata emotionaalisesti) samoille faktoreille sekä miesten että naisten ryhmissä. Osa verbeistä kuitenkin latautui tilastollisesti merkitsevästi vain miesten tai naisten ryhmässä. Faktoreille myös latautui varsinaisten verbien lisäksi sukupuolen ohjaamana muutama ylimääräinen verbi. Informaation kriittinen organisointi -faktorille latautuivat miesten aineistossa ylimääräisinä verbit tai verbi-ilmaukset ajatella, tuntea emotionaalisesti, kohdata emotionaalisesti ja hyväksyä, ja Informaation integrointi -faktorille verbit elehtiä ja konstruoida. Naisten aineistossa ei näille faktoreille latautunut ylimääräisiä verbejä. Informaation omaksuminen -faktorille ei miesten aineiston analyysissa latautunut ylimääräisiä verbejä tai verbiilmauksia, naisten aineistosta sen sijaan tälle faktorille latautuivat ylimääräisinä vetää johtopäätös, kohdata emotionaalisesti ja sitoa asiat. (Ks. liite 3, kohdat "Lisäksi".)

Myöskään syyttäjien virkavuosien määrällä ei ollut tilastollisesti merkitsevää yhteyttä siihen, miten verbit latautuivat eri faktoreille. Sen sijaan pienehköjä tilastollisia eroja löytyi eri ikäryhmien väliltä: $31-40$-vuotiaat (28 vastaajaa) syyttäjät olivat ainoa ryhmä, jonka aineistosta löytyi viitteitä kuuntelemisen mieltämisestä vuorovaikutukseen ja suhteiden rakentamiseen liittyväksi viestintäkäyttäytymiseksi. Tässä ryhmässä latautuivat myös kuuntelemisen liittäminen informaation hankkimiseen ja integrointiin samalle faktorille. Informaation organisointi kriittisesti muodosti edelleen oman faktorinsa. Myös 41-50-vuotiaat syyttäjät (25 vastaajaa) liittivät kuuntelemisen informaation kriittiseen arviointiin ja informaation organisointiin. Nämä muodostivat omat faktorinsa, informaation omaksuminen ja integroiminen kuuntelemalla latautuivat samalle faktorille, ja kuuntelemisen ihmissuhteiden rakentamiseen liittävä faktori puuttui.

\section{POHDINTA}

Kuuntelemisen käsitteelle annettujen merkityssisältöjen on todettu ennustavan kuuntelemiskäyttäytymistä. Tässä tutkimuksessa lähdettiin kartoittamaan näitä merkityssisältöjä LCI-mittarin avulla. LCI-mittari vaikuttaa tämän tutkimuksen perusteella toimivan kehittelyvaiheessa olevaksi mittariksi nykyisessä 48 verbiä käsittävässä muodossaan suomenkielisessä ympäristössä melko hyvin. 
Sen avulla näyttää olevan mahdollista päästä tarkastelemaan tutkimuksen kohdejoukon, käräjätuomareiden ja syyttäjien, kuuntelemisen käsitteelle antamia merkityssisältöjä. Mittari antaa vastauksia sihen, miten vastaajat rakentavat kuuntelemisen semanttista kenttää eli miten he ymmärtävät kuuntelemisen. Lisätutkimusta sen sijaan tarvitaan, jos halutaan osoittaa mahdollisia kytkentöjä kuuntelemiskäsitysten ja sen välillä, mihin vastaajat käyttävät kuuntelemistaan.

Tutkimus siis tarkasteli, millaisia merkityssisältöjä käräjätuomarit ja syyttäjät antavat kuuntelemisen käsitteelle. Heitä ei pyydetty lähestymään aihetta erityisesti työtehtäväänsä ajatellen, joten suoria yhteyksiä kuuntelemiseen liittyvien käsitysten ja työtehtävän välille ei voida vetää. Tuloksia voidaan kuitenkin tarkastella näiden ammattiryhmien antamana yleisesti. Taustamuuttujista riippumatta käräjätuomareiden ja syyttäjien käsitykset kuuntelemisesta liittyvät erityisesti informaation kriittiseen organisointiin sekä informaation integroimiseen ja omaksumiseen. Vastaajat myös näyttävät pitävän kuuntelemista pääasiassa subjektiivisena toimintona, sillä heidän läheisesti kuuntelemiseen liittämiensä verbien merkityssisällöt kuvaavat tekemistä, joka liittyy vain kuuntelijaan. Tällöin suhteiden rakentaminen ja ylläpitäminen rajautuu kuuntelemisen keskiön ulkopuolelle. Tätä havaintoa tukevat myös verbit, jotka käräjätuomarit ja syyttäjät mielsivät kauimpana kuuntelemisesta oleviksi. Antaa myöten/periksi, tehdä ehdotus ja testata vaativat vuorovaikutussuhteen olemassaolon tiedostamista myös kuuntelemisen näkökulmasta, sillä kyseiset viestintätoiminnot eivät onnistu ilman viestintäkumppania. Kun vastaajat mieltävät kuuntelemisen lähinnä yksilölähtöiseksi toiminnaksi, tulee ymmärrettäväksi, ettei vuorovaikutussuhdetta vaativa viestintäkäyttäytyminen erityisesti korostu. Tätä tulosta tukevat myös aiemmat tutkimukset erityisesti syyttäjän vuorovaikutus- ja viestintäorientaatiosta (ks. Välikoski 2004a).

Tämän tutkimuksen tulokset poikkesivat vastaavien kuuntelemiseen liittyviä käsityksiä tarkastelevien tutkimusten tuloksista, joissa kuuntelemiselle annetut merkitykset ovat yleensä liittyneet kognitiiviseen informaation organisointiin, sanoman kriittiseen arviointiin, suhteiden rakentamiseen sekä oppimiseen ja informaation yhdistelyyn (Imhof \& Janusik 2006; Imhof, Välikoski \& Janusik 2006). Vuorovaikutukseen ja suhteiden rakentamiseen liittyvän kuuntelemisen puuttuminen korostui erityisesti verrattaessa saatuja tuloksia suomalaisten sairaanhoitajien (Artkoski 2008), yhdysvaltalaisten sairaanhoitajien (Bond ym. 2008) ja yhdysvaltalaisten, saksalaisten ja suomalaisten yliopisto-opiskelijoiden (Imhof, Välikoski \& Janusik 2006) kuuntelemiskäsityksiin, joissa vuorovaikutus ja suhteiden rakentaminen liittyivät kiinteästi kuuntelemiselle annettuihin merkityssisältöihin. Koska tämän tutkimuksen tuloksissa faktori, joka kuvasi informaation kriittistä organisointia, kuitenkin sisälsi myös molemminpuolisen suostuttelun ja kuuntelemisen kannalta merkityksellisiä verbejä, kuten tehdä ehdotus, sopia ja auttaa, on mahdollista, että yhteistyötä edistävä viestintäkäyttäytyminen ja kriittisempi, vastakkainasettelua havainnollistava viestintäkäyt- 
täytyminen limittyvät kyselyyn vastanneiden käräjätuomareiden ja syyttäjien kuuntelukäsityksissä (vrt. Imhof \& Janusik 2006).

Muissa tutkimuksissa (Imhof \& Janusik 2006; Imhof, Välikoski \& Janusik 2006) kuuntelemiseen liittyvä informaation organisointi ja sanoman kriittinen arviointi ovat latautuneet kahdelle eri faktorille, mutta tässä tutkimuksessa ne osuivat johdonmukaisesti samalle faktorille taustamuuttujista riippumatta. Käräjätuomarit ja syyttäjät näyttävät siten mieltävän kuuntelemisen toiminnaksi, jossa vuorovaikutukseen liittyy viestin sisällön kriittinen arviointi ja informaation organisointi - heidän kuuntelemisensa keskittynee siis kuuntelutilanteessa informaation subjektiiviseen, kognitiiviseen prosessointiin vuorovaikutussuhteita rakentavan kuuntelemisen sijaan. Koska 1990-luvulla tapahtuneen oikeudenkäyntiuudistuksen jälkeen erityisesti syyttäjän välitön vuorovaikutus jutun asianosaisten ja todistajien kanssa lisääntyi, kuuntelemisen ymmärtäminen pelkästään informaation kriittistä organisointia sekä informaation integroimista ja omaksumista palvelevana viestintäkäyttäytymisenä ei välttämättä enää riitä. Syyttäjän vuorovaikutussuhteita rakentava kuunteleminen saattaisi mahdollistaa tarvittavan informaation saamisen aiempaa paremmin, sillä todistajien mukaan vastaaminen helpottuu, jos vuorovaikutus istuntokäsittelyssä on luontevaa ja toimivaa (ks. Välikoski 2000). Informaation kriittisen organisoinnin korostuminen vastauksissa on mielenkiintoista myös siksi, ettei vastaajia ohjeistettu ajattelemaan kuuntelemista erityisesti työtehtävässään (ks. kyselyohjeistus liitteessä 1). On todennäköistä, että työtehtävä on kuitenkin ohjannut kysymyksiin vastaamista, kerättiinhän vastaukset ammatillisella täydennyskoulutuskurssilla.

Tämän tutkimuksen tuloksissa faktoreille latautui varsinaisten verbien (ks. taulukko 4) lisäksi sukupuolen ohjaamana muutama ylimääräinen verbi. Niiden tarkastelu indikoi, että naiskäräjätuomarit ja -syyttäjät saattavat mieltää kuuntelemisen informaation omaksumisen ohessa toiminnaksi, jossa sidotaan uudet asiat yhteen, vedetään johtopäätöksiä kuullun perusteella ja kohdataan viestintäkumppani emotionaalisesti. Miehet puolestaan näyttivät liittävän emotionaalisen kohtaamisen informaation kriittisen organisoinnin yhteyteen. Miehet liittivät lisäksi verbi-ilmauksen tuntea emotionaalisesti informaation kriittisen organisoinnin yhteyteen, naisten ryhmässä se ei latautunut ollenkaan. Vaikka verbi-ilmaus kohdata emotionaalisesti latautui eri faktoreille sukupuolesta riippuen, sekä miehet että naiset näyttävät yhdistävän kuuntelemisen kohtaamiseen tunnetasolla, vaikka varsinaista vuorovaikutuksen ja suhteiden rakentamisesta kertovaa faktoria ei vastauksista muodostunutkaan.

Tässä tutkimuksessa osa verbeistä latautui useammalle faktorille, joten niiden pohjalta ei voinut tehdä johtopäätöksiä kuuntelemiseen liittyvistä käsityksistä. Se, etteivät vuorovaikutusta ja suhteiden rakentamista kuvaavat verbit latautuneet tilastollisesti merkitsevästi erikseen millekään faktorille, saattaa liittyä siihen, ettei henkilöiden välisten suhteiden rakentaminen ole perinteisesti ollut keskeistä oikeussalissa tapahtuvan kuuntelemisen kannalta. Koska käräjätuomarilla ja syyttäjällä on toiminnallinen vastuu oikeudenkäynnin etenemisestä eri käsittelyvaiheissa, heidän kuuntelemisensa keskittyy usein oleellisen informaation ja tosiasioiden löytämiseen, 
minkä myötä oikean tuomion langettaminen on aineellisesti ja prosessuaalisesti mahdollista.

Uudistuneen oikeudenkäyntimenettelyn suullisuuden myötä oikeudenkäynneistä tuli aiempaa havainnollisempia ja selkeämpiä, mikä siis lisäsi kuuntelemisen merkitystä käräjätuomareiden ja syyttäjien työssä. Kukaan ei ole oikeussalissa sattumalta, vaan jokaisella istuntokäsittelyyn tai sovitteluun osallistuvalla on omat intressinsä. Kuunteleminen on tällaisessa tilanteessa avainasemassa, sillä päätettäessä henkilölle tärkeistä asioista tämän kuulluksi tulemisen tarve on voimakas. Suhteiden rakentamista ohjaavan kuuntelemiskäsityksen soveltaminen tilanteeseen onkin välttämätöntä vuorovaikutuksen onnistumisen kannalta. Vain miesvastaajien ryhmässä oli viitteitä siitä, että vuorovaikutusta emotionaalisella tasolla rakentavan kuuntelemiskäsityksen merkityssisältö oli olemassa. Koska kuuntelemisen käsitteelle annettujen merkityssisältöjen on todettu ennustavan kuuntelemiskäyttäytymistä, voi vuorovaikutuksen rakentamiseen liittyvän kuuntelemiskäsityksen puuttuminen käytännössä näkyä istuntokäsittelyissä ja sovitteluissa faktatietoon suuntautuneiden syyttäjien ja käräjätuomareiden puutteellisena viestintäosaamisena: kuuntelemista ei ajatella eikä osata liittää vuorovaikutuksen tehokkaaseen säätelyyn, jonka tuloksena esimerkiksi osapuolia tyydyttävät sovintoehdotukset olisivat mahdollisia. Tämän viestintäosaamisen tiedostaminen ja siinä kehittyminen todennäköisesti kuitenkin takaisi käräjätuomareille ja syyttäjille mahdollisuudet vastata niihin vuorovaikutuksellisiin ammattitaitovaatimuksiin, joita oikeudenkäyntimenettelyn uudistaminen on heille asettanut.

Koska kognitiivisten kuuntelemiseen liittyvien käsitysten on aiemmissa tutkimuksissa (Imhof \& Janusik 2006; Imhof, Välikoski \& Janusik 2006) havaittu olevan suhteellisen kulttuurisidonnaisia, jatkossa on tarkoitus vertailla tässä tutkimuksessa saatuja tuloksia yhdysvaltalaisten oikeustieteellisen koulutuksen saaneiden henkilöiden käsityksiin. Vastaajiksi etsitään pääasiassa tuomareina ja syyttäjinä toimivia tai joskus toimineita henkilöitä. Mittarin jatkotestausta ajatellen sen käyttö erilaisista ammatti- ja ikäryhmistä koostuvien vastaajien kuuntelemiseen liittyvien käsitysten mittaamiseen antaisi arvokasta tietoa mittarin toimivuudesta ja kehittämistarpeista. Mittarilla päästiin tässä tutkimuksessa tarkastelemaan vastaajien kuuntelemisen käsitteelle antamia merkityssisältöjä, mutta vasta vastaajien viestintäkäyttäytymistä observoimalla saataisiin tietoa siitä, kuinka heidän kuuntelemisen käsitteelle antamansa merkityssisällöt ennustavat kuuntelemista käytännössä.

\section{KIRJALLISUUS}

Ala-Kortesmaa, S. 2008. Listening in legal context. Teoksesssa M. Imhof (toim.) Listen and make the connection! Proceedings of the $28^{\text {th }}$ Annual Convention of the International Listening Association. Tönning: Der Andere Verlag, 99-116. Artkoski, M. 2008. Subjective listening concepts in the Finnish nursing context.

Esitelmä pidetty ILA:n konferenssissa 2008. Portland, ME. 
Bodie, G. D., Välikoski, T.-R. \& Worthington, D. L. 2008. Establishing a stable factor structure for a recently developed Listening Concepts Inventory.

Esitelmä pidetty ILA:n konferenssissa 2008. Portland, ME.

Bond, C., Davis, J., Thompson, C. R., Foley, A. S. \& DeWitt, J. 2008. An examination of listening concepts in the healthcare context: differences among nurses, physicians, and administrators. Esitelmä pidetty ILA:n konferenssissa 2008. Portland, ME.

Bostrom, R. N. 1997. The process of listening. Teoksessa O. D. W. Hargie (toim.) Handbook of communication skills. 2. painos. Lontoo: Routledge, 236-258.

Brownell, J. 1990. Perceptions of effective listeners: A management study. The Journal of Business Communication 27 (4), 401-415.

Brownell, J. 2002. Listening: attitudes, principles, and skills. 2 painos. Boston: Allyn \& Bacon.

Cooper, M. 1998. NIU Listening exam: assessing college level listening skills. Journal of the International Listening Association 2, 53-74.

Ervasti, K. 1997. Alioikeusuudistuksen seuranta: riita-asiat tilastojen ja oikeudenkäyntiasiakirjojen valossa. Oikeuspoliittisen tutkimuslaitoksen julkaisuja 140.

Fitch-Hauser, M. 1990. Making sense of data: constructs, schemas, and concepts. Teoksessa R. Bostrom (toim.) Listening behavior: measurement and applications. New York: Guilford, 76-90.

Fitch-Hauser, M. \& Hughes, A. 1992. The conceptualization and measurement of listening. Journal of the International Listening Association 6, 6-22.

Gabarro, J. J. 1991. Retrospective commentary. Harvard Business Review 69 (6), 108-109.

Gilchrist, J. A. \& Van Hoeven, S. A. 1994. Listening as an organizational construct. International Journal of Listening 8, 6-30.

Golen, S. 1990. A factor analysis of barriers to effective listening. The Journal of Business Communication, 27, 25-36.

Guadagnoli, E. \& Velicer, W. F. 1988. Relationship of sample size to the stability of component patterns. Psychological Bulletin, 103, 265-275.

Haavisto, V. 2002. Court work in transition: an activity-theoretical study of changing work practices in a Finnish district court. Helsinki: Helsinki University Press.

Hallintolaki 434/2004.

Halsband, U., Krause, B., Sipilä, H., Teräs, M. \& Laihinen, A. 2002. PET studies on the memory processing of word pairs in bilingual Finnish-English subjects. Behavioral Brain Research 132, 47-57.

HE 32/2001vp = Hallituksen esitys laiksi oikeudenkäymiskaaren ja eräiden muiden lakien riita- asiain valmistelua, pääkäsittelyä sekä hakemusasioiden käsittelyä koskevien säännösten muuttamisesta 32/2001vp.

Huhta, A., Kohonen, V., Kurki-Suonio, L. \& Luoma, S. 1997. Current developments and alternatives in language assessment. Proceedings of LTRC 96. Jyväskylä: Jyväskylän yliopisto. 
Imhof, M. 2003. The social construction of the listener: listening behavior across situations, perceived listener status, and cultures. Communication Research Reports, 20, 369-378.

Imhof, M. \& Janusik, L. A. 2006. Development and validation of the ImhofJanusik Listening Concepts Inventory to measure listening conceptualization differences between cultures. Journal of Intercultural Communication Research 35 (2), 79-98.

Imhof, M., Välikoski, T.-R. \& Janusik, L. 2006. Exploring intercultural listening competencies. Esitelmä pidetty ILA:n konferenssissa 2006. Salem, OR.

Koivunen, N. 2007. Kohti kuuntelevaa johtamiskulttuuria: johtajuustutkimuksen ja estetiikan yhtymäkohtia. Hallinnon Tutkimuksen Seura 26 (2), 33-46.

Koponen, P. 2004. Syyttäjän uudet tehtävät pääkäsittelyssä. Teoksessa A.

Anhava, P. Koponen \& T.-R. Välikoski (toim.) Syyttäjän uudet haasteet - syyttäjä ja rikosasian suullinen käsittely. Valtakunnansyyttäjänvirasto, Julkaisusarja nro 4. Helsinki: Edita Prima, 7-10.

Korpijaakko-Huuhka, A.-M., Pekkala, S. \& Heimo, H. (toim.) 2005. Kielen ja kognition suhde. Helsinki: Puheen ja kielen tutkimuksen yhdistyksen julkaisuja 37.

Kostiainen, E. 2003. Viestintä ammattiosaamisen ulottuvuutena. Jyväskylän yliopisto. Jyväskylä Studies in Humanities 1.

Laki riita-asioiden sovittelusta yleisissä tuomioistuimissa 26.8.2005/663.

Laki rikosasioiden ja eräiden riita-asioiden sovittelusta 9.12.2005/1015.

Lakia rikosasioiden käsittelystä valmistelevan työryhmän mietintö 1/1993.

Laukkanen, A.-M., Björkner, E. \& Sundberg, J. 2005. Throaty voice quality: subglottal pressure, voice source and formant characteristics. Journal of Voice 29, 25-37.

LaVM 12/2002vp $=$ Lakivaliokunnan mietintö 12/2002vp.

Metsämuuronen, J. 2003. Tutkimuksen tekemisen perusteet ihmistieteissä. Helsinki: International Methelp.

Mikkola, L. 2006. Tuen merkitys potilaan ja hoitajan vuorovaikutuksessa. Jyväskylän yliopisto. Jyväskylä Studies in Humanities 66 .

Mäkinen, M. 2005. Early strengthening of phonological awareness supports the process of learning to read. Tampereen yliopisto. Kasvatustieteellisen laitoksen julkaisuja.

Nichols, R. 1948. Factors in listening comprehension. Speech Monographs, 15, 154-163.

Nyfors, R. 1995. Puheviestintää ja ilmaisutaitoa kehittämään. Opas äidinkielen ja suullisen ilmaisun testin ja arvioinnin järjestämiseen peruskoulun päättöluokilla. Helsingin yliopisto. Studia Pedagogica 6.

Peräkylä, A. 2004. Two traditions of interaction research. British Journal of Social Psychology 43 (1), 1-20.

Rogers, C. R. \& Rothelisberger, F. J. 1952. Barriers and gateways to communication. Harvard Business Review 69 (6), 105-111.

RoL 97/689 = Laki rikosasioiden käsittelystä 97/689.

Suomen Hallitusmuoto 94/1919. 
Suoninen, E. 2005. Persuasion in social work interviewing. Qualitative Social Work 4 (4), 469-487.

Tiuraniemi, J. 2004. Esimiestyö ja sosioemotionaaliset ongelmat työyhteisössä. Hallinnon Tutkimus 3, 61-69.

Työturvallisuuslaki 738/2002.

Valkonen, T. 2001. Lukiolaisten kommunikaatiovalmiudet. Lukion 2. vuoden opiskelijoiden kommunikaatiovalmiuksien kansallinen arviointi 2000. Helsinki: Opetushallitus.

Villaume, W. A. \& Weaver, J. B. 1996. A factorial approach to establishing reliable listening measures from the WBLT and the KCLT: full information factor analysis of dichotomous data. International Journal of Listening, 10, $1-20$.

Välikoski, T.-R., Ilomäki, I., Mäki, E. \& Janusik, L. A. 2005. Kuunteleminen keskustelussa - yhdysvaltalaisen ja suomalaisen aineiston vertailu. Teoksessa T.-R. Välikoski, E. Kostiainen, E. Kyllönen \& L. Mikkola (toim.) Prologi: puheviestinnän vuosikirja 2005. Jyväskylä: Prologos.

Välikoski, T.-R. 2000. Todistajana rikosoikeudenkäynnissä: selvitys rikosoikeudenkäynnin viestinnällisestä luonteesta todistajan näkökulmasta. Tampereen yliopisto. Puheopin laitos. Raportteja 1/2000.

Välikoski, T.-R. 2004a. Puheviestintä ja rikosasian oikeudenistunto. Teoksessa A. Anhava, P. Koponen \& T.-R. Välikoski (toim.) Syyttäjän uudet haasteet - syyttäjä ja rikosasian suullinen käsittely. Valtakunnansyyttäjänvirasto, Julkaisusarja nro 4. Helsinki: Edita Prima, 14-20.

Välikoski, T.-R. 2004b. The criminal trial as a speech communication situation. Acta Universitatis Tamperensis 1011. Tampere: University Press.

Wolvin, A. D. \& Coakley, C. G. 2000. Listening education in the $21^{\text {st }}$ century. International Journal of Listening, 14, 143-152. 


\section{LIITTEET}

\section{LIITE 1. Imhof-Janusik Listening Concept Inventory (LCI), versio 2}

Mitä kuunteleminen mielestäsi on? Kuunteleminen on monitasoinen käsite, ja se voidaan määritellä eri tavoin riippuen esimerkiksi määrittelijän kokemuksista ja kulttuurista. Tässä kyselyssä halutaan selvittää ihmisten käsityksiä kuuntelemisesta. Koska jokainen on oman käsitteensä asiantuntija, vaihtoehtoja on useita.

Mieti, miten läheinen tai samanlainen esitetty käsite on kuuntelemisen kanssa:

\begin{tabular}{|c|c|c|c|c|c|}
\hline & $\begin{array}{c}\text { ei lainkaan } \\
\text { lähellä }\end{array}$ & $\begin{array}{c}\text { jotenkin } \\
\text { tekemisissä }\end{array}$ & $\begin{array}{c}\text { melko } \\
\text { samanlainen }\end{array}$ & $\begin{array}{c}\text { lähes } \\
\text { Identtinen }\end{array}$ & Identtinen \\
\hline \multicolumn{6}{|l|}{$\begin{array}{l}\text { 1. olla mukana } \\
\text { (keskust.) }\end{array}$} \\
\hline \multicolumn{6}{|c|}{ 2. osoittaa empatiaa } \\
\hline \multicolumn{6}{|c|}{ 3. kuulla sattumalta } \\
\hline \multicolumn{6}{|l|}{ 4. salakuunnella } \\
\hline \multicolumn{6}{|l|}{ 5. oppia } \\
\hline \multicolumn{6}{|l|}{ 6. analysoida } \\
\hline \multicolumn{6}{|l|}{ 7. nauttia jostakin } \\
\hline \multicolumn{6}{|l|}{ 8. valikoida } \\
\hline \multicolumn{6}{|l|}{ 9. ymmärtää } \\
\hline \multicolumn{6}{|l|}{ 10. arvostaa } \\
\hline \multicolumn{6}{|l|}{ 11. erotella } \\
\hline \multicolumn{6}{|l|}{ 12. tulkita } \\
\hline \multicolumn{6}{|l|}{ 13. elehtiä } \\
\hline \multicolumn{6}{|c|}{$\begin{array}{l}\text { 14. purkaa sanoma, } \\
\text { jäsentää }\end{array}$} \\
\hline \multicolumn{6}{|l|}{$\begin{array}{l}\text { 15. kerätä } \\
\text { informaatiota }\end{array}$} \\
\hline \multicolumn{6}{|l|}{ 16. havainnoida } \\
\hline \multicolumn{6}{|c|}{ 17. kuunnella tarkasti } \\
\hline \multicolumn{6}{|l|}{ 18. mitätöidä } \\
\hline \multicolumn{6}{|l|}{ 19. totella } \\
\hline \multicolumn{6}{|c|}{ 20. jakaa (ajatukset) } \\
\hline \multicolumn{6}{|l|}{ 21. konstruoida } \\
\hline \multicolumn{6}{|l|}{ 22. ajatella } \\
\hline \multicolumn{6}{|l|}{$\begin{array}{l}\text { 23. tuntea } \\
\text { (emotionaal.) }\end{array}$} \\
\hline 24. keskeyttää & & & & & \\
\hline
\end{tabular}


LIITE 1. (JATKUU)

\begin{tabular}{|c|c|c|c|c|c|}
\hline & $\begin{array}{c}\text { ei lainkaan } \\
\text { lähellä }\end{array}$ & $\begin{array}{c}\text { jotenkin } \\
\text { tekemisissä }\end{array}$ & $\begin{array}{c}\text { melko } \\
\text { samanlainen }\end{array}$ & $\begin{array}{c}\text { lähes } \\
\text { identtinen }\end{array}$ & identtinen \\
\hline \multicolumn{6}{|l|}{$\begin{array}{l}\text { 25. järjestää } \\
\text { informaatiota }\end{array}$} \\
\hline \multicolumn{6}{|l|}{ 26. verrata } \\
\hline \multicolumn{6}{|l|}{ 27. arvioida } \\
\hline \multicolumn{6}{|l|}{ 28. perustella } \\
\hline \multicolumn{6}{|l|}{ 29. olla kriittinen } \\
\hline \multicolumn{6}{|l|}{ 30. varastoida tietoa } \\
\hline \multicolumn{6}{|l|}{ 31. tehdä ehdotus } \\
\hline \multicolumn{6}{|c|}{ 32. vetää johtopäätös } \\
\hline \multicolumn{6}{|l|}{$\begin{array}{l}\text { 33. vastata } \\
\text { kysymyksiin }\end{array}$} \\
\hline \multicolumn{6}{|l|}{ 34. "pantata" tietoa } \\
\hline \multicolumn{6}{|l|}{$\begin{array}{l}\text { 35. antaa myöten, } \\
\text { periksi }\end{array}$} \\
\hline \multicolumn{6}{|l|}{ 36. sopia } \\
\hline \multicolumn{6}{|l|}{$\begin{array}{l}\text { 37. kohdata } \\
\text { (emotionaal.) }\end{array}$} \\
\hline \multicolumn{6}{|l|}{ 38. auttaa } \\
\hline \multicolumn{6}{|l|}{ 39. lohduttaa } \\
\hline \multicolumn{6}{|l|}{ 40. sitoa (asiat) } \\
\hline \multicolumn{6}{|l|}{ 41. sosiaalistua } \\
\hline \multicolumn{6}{|l|}{ 42. testata } \\
\hline \multicolumn{6}{|l|}{ 43. tiedustella } \\
\hline \multicolumn{6}{|l|}{ 44. olla varuillaan } \\
\hline \multicolumn{6}{|l|}{ 45. hyväksyä } \\
\hline \multicolumn{6}{|l|}{$\begin{array}{l}\text { 46. toivottaa } \\
\text { tervetulleeksi }\end{array}$} \\
\hline \multicolumn{6}{|l|}{ 47. tulla tietoiseksi } \\
\hline $\begin{array}{l}\text { 48. ymmärtäää } \\
\text { (aavistaa) }\end{array}$ & & & & & \\
\hline
\end{tabular}




\section{LIITE 2. Faktorit, keskiarvot ja keskihajonnat, tarkastelun ulkopuolelle jääneet}

verbit, koko aineisto $(\mathrm{N}=120)$.

\begin{tabular}{|c|c|c|c|c|c|c|}
\hline Verbit & \begin{tabular}{|l|} 
Faktori 1: \\
Informaation \\
kriittinen \\
organisointi
\end{tabular} & $\begin{array}{l}\text { Faktori 2: } \\
\text { Informaation } \\
\text { integrointi }\end{array}$ & $\begin{array}{l}\text { Faktori 3: } \\
\text { Informaation } \\
\text { omaksuminen }\end{array}$ & Keskiarvot & Keskihajonnat & $\begin{array}{l}\text { Tarkastelun } \\
\text { ulkopuolelle } \\
\text { jääneet } \\
\text { verbit }\end{array}$ \\
\hline $\begin{array}{l}\text { Olla mukana } \\
\text { keskust. }\end{array}$ & & & & 2,88 & 1,009 & $x$ \\
\hline $\begin{array}{l}\text { osoittaa } \\
\text { empatiaa }\end{array}$ & & & & 2,30 &, 913 & $x$ \\
\hline kuulla sattumalta & & & & 1,97 &, 921 & $x$ \\
\hline salakuunnella & & & & 2.69 & 1,172 & $x$ \\
\hline oppia & & & & 3,35 & 8,856 & $\mathrm{x}$ \\
\hline analysoida & & ,798 & & 2,20 & 1,085 & \\
\hline nauttia_jstk & & ,825 & & 1,80 &, 949 & \\
\hline valikoida & & ,774 & & 2,18 & 1,010 & \\
\hline ymmärtää & &, 636 & & 2,69 & 1,165 & \\
\hline arvostaa & & ,716 & & 2,16 & ,996 & \\
\hline erotella & & ,783 & & 2,17 & 1,007 & \\
\hline tulkita & & ,688 & & 2,32 & 1,006 & \\
\hline elehtiä & & & & 1,78 & 918 & $x$ \\
\hline $\begin{array}{l}\text { purkaa sanoma, } \\
\text { jäsentää }\end{array}$ & & &, 560 & 2,92 & 1,078 & $x$ \\
\hline $\begin{array}{l}\text { kerätä } \\
\text { informaatiota }\end{array}$ & & & ,702 & 3,23 & ,991 & \\
\hline havainnoida & & & ,643 & 3,42 & 1,017 & \\
\hline \begin{tabular}{|l|}
$\begin{array}{l}\text { kuunnella } \\
\text { tarkasti }\end{array}$ \\
\end{tabular} & & & & 3,46 & 1,420 & $x$ \\
\hline mitätöidä & & & & 1,86 &, 919 & $x$ \\
\hline totella & & & & 1,77 & 896 & $x$ \\
\hline jakaa ajatukset & & & & 2,22 & 927 & $x$ \\
\hline konstruoida & & , 507 & & 2,03 & 943 & $x$ \\
\hline ajatella & & ,506 & & 2,24 & 1,130 & $x$ \\
\hline $\begin{array}{l}\text { tuntea } \\
\text { emotionaalisesti }\end{array}$ &, 558 & & & 1,90 & 1,016 & $x$ \\
\hline keskeyttää & ,732 & & & 1,68 & 917 & \\
\hline $\begin{array}{l}\text { järjestää } \\
\text { informaatiota }\end{array}$ &, 517 & & & 2,16 & 1,123 & $\mathrm{x}$ \\
\hline verrata & ,697 & & & 2,05 & 1,060 & \\
\hline
\end{tabular}


LIITE 2. (JATKUU)

\begin{tabular}{|c|c|c|c|c|c|c|}
\hline Verbit & $\begin{array}{l}\text { Faktori 1: } \\
\text { Informaation } \\
\text { kriittinen } \\
\text { organisointi }\end{array}$ & $\begin{array}{l}\text { Faktori 2: } \\
\text { Informaation } \\
\text { integrointi }\end{array}$ & $\begin{array}{l}\text { Faktori 3: } \\
\text { Informaation } \\
\text { omaksuminen }\end{array}$ & Keskiarvo & Keskihajonnat & $\begin{array}{l}\text { Tarkastelun } \\
\text { ulkopuolelle } \\
\text { jääneet } \\
\text { verbit }\end{array}$ \\
\hline arvioida & ,691 & & & 2,08 & 1,142 & \\
\hline perustella & ,783 & & & 1,97 & 1,126 & \\
\hline olla kriittinen & 738 & & & 2,13 & 1,144 & \\
\hline $\begin{array}{l}\text { varastoida } \\
\text { informaatiota }\end{array}$ & & & ,753 & 2,26 & 1,185 & \\
\hline tehdä ehdotus & ,668 & & & 1,64 & 1,002 & \\
\hline $\begin{array}{l}\text { vetää } \\
\text { johtopäätös }\end{array}$ & ,633 & & & 2,15 & 1,142 & \\
\hline $\begin{array}{l}\text { vastata } \\
\text { kysymyksiin }\end{array}$ & ,733 & & & 1,97 & 1,115 & \\
\hline pantata tietoa & ,768 & & & 1,44 & 838 & \\
\hline $\begin{array}{l}\text { antaa myöten } \\
\text { tai periksi }\end{array}$ & ,671 & & & 1,58 &, 866 & \\
\hline sopia & ,745 & & & 1,95 & 1,091 & \\
\hline $\begin{array}{l}\text { kohdata } \\
\text { emotionaalisesti }\end{array}$ & & & & 3,03 & 8,909 & $x$ \\
\hline auttaa &, 664 & & & 2,00 & 1,108 & \\
\hline lohduttaa & & & & 2,85 & 8,921 & $\bar{x}$ \\
\hline sitoa asiat &, 546 & & & 2,06 & 1,117 & $x$ \\
\hline sosiaalistua & ,581 & & & 2,06 & 1,040 & $x$ \\
\hline testata & ,773 & & & 1,65 & 1,001 & \\
\hline tiedustella & ,642 & & & 1,91 & 1,061 & \\
\hline olla varuillaan &, 750 & & & 1,76 & 970 & \\
\hline hyväksyä & & & & 1,92 & 1,074 & \\
\hline $\begin{array}{l}\text { toivottaa } \\
\text { tervetulleeksi }\end{array}$ & & & & 1,87 & 1,130 & $x$ \\
\hline tulla tietoiseksi & ,713 & & & 2,32 & 1,202 & \\
\hline $\begin{array}{l}\text { ymmärtää } \\
\text { (aavistaa) }\end{array}$ & & & ,692 & 1,74 & 1,208 & \\
\hline
\end{tabular}

\section{Pääkomponenttianalyysi.}

Varimax-rotaatio.

Lihavoituina verbit, jotka latautuivat merkittävästi $(>, 60)$.

Taulukkoon ei ole merkitty faktorilatauksia, jotka saivat arvokseen alle ,500. 
LIITE 3. Faktoreille latautuneet verbit sukupuolijakauman mukaan.

\begin{tabular}{|c|c|c|c|}
\hline Faktori & Latautuneet verbit & Miehet & Naiset \\
\hline \multirow{14}{*}{$\begin{array}{l}\text { Informaation kriittinen } \\
\text { organisointi }\end{array}$} & keskeyttää & & $x$ \\
\hline & verrata & $\mathrm{x}$ & $x$ \\
\hline & arvioida & $x$ & $x$ \\
\hline & perustella & $x$ & $x$ \\
\hline & olla kriittinen & $x$ & $x$ \\
\hline & tehdä ehdotus & & $x$ \\
\hline & vetää johtopäätös & $x$ & \\
\hline & vastata kysymyksiin & & $x$ \\
\hline & pantata tietoa & & $x$ \\
\hline & antaa myöten/periksi & & $x$ \\
\hline & auttaa & $x$ & \\
\hline & testata & & $\mathrm{x}$ \\
\hline & tiedustella & $x$ & \\
\hline & olla varuillaan & $\mathrm{x}$ & \\
\hline \multirow[t]{4}{*}{ Lisäksi } & ajatella & $x$ & \\
\hline & tuntea emotionaalisesti & $x$ & \\
\hline & kohdata emotionaalisesti & $x$ & \\
\hline & hyväksyä & $x$ & \\
\hline \multirow{7}{*}{ Informaation integrointi } & analysoida & $\mathrm{x}$ & $\mathrm{x}$ \\
\hline & nauttia jostakin & $x$ & $x$ \\
\hline & valikoida & $x$ & $x$ \\
\hline & ymmärtää & $x$ & $x$ \\
\hline & arvostaa & $x$ & $x$ \\
\hline & erotella & $x$ & $x$ \\
\hline & tulkita & $x$ & $x$ \\
\hline \multirow[t]{3}{*}{ Lisäksi } & elehtiä & $x$ & $x$ \\
\hline & oppia & $x$ & $x$ \\
\hline & konstruoida & $x$ & \\
\hline \multirow{3}{*}{ Informaation omaksuminen } & purkaa sanoma/jäsentää & $x$ & \\
\hline & varastoida informaatiota & $x$ & $x$ \\
\hline & fulla tietoiseksi & $x$ & $\mathrm{x}$ \\
\hline \multirow[t]{3}{*}{ Lisäksi } & vetää johtopäätös & $x$ & $x$ \\
\hline & kohdata emotionaalisesti & & $x$ \\
\hline & sitoa asiat & & $x$ \\
\hline
\end{tabular}

